\title{
THE EFFECTS OF FOLIAR FEEDING OF COMPATIBLE ORGANIC SOLUTES ON AGRONOMIC TRAITS OF SAFFLOWER
}

\author{
MOHSEN JANMOHAMMADI*, FARZANEH ASADI, NASER SABAGHNIA, AMIN ABBASI, \\ MOJTABA NOURAEIN, FARIBORZ SHEKARI
}

University of Maragheh, Iran

\begin{abstract}
JANMOHAMMADI, M. - ASADI, F. - SABAGHNIA, N. -ABBASI, A. - NOURAEIN, M. - SHEKARI, F.: The effect of foliar feeding of compatible organic solutes on agronomic traits of safflower. Agriculture (Pol'nohospodárstvo), vol. 63, 2017, no. 4, pp. 128-141.
\end{abstract}

Safflower is originated from Iran and is tolerant against water deficit stress. However, in semi-arid Mediterranean climate terminal drought and heat stress adversely affect the safflower production. In order to investigate the influence of foliar application of proline $(\operatorname{Pr})(10$ and $20 \mathrm{mM})$ and glycinebetaine $(\mathrm{GB})(2$ and $4 \mathrm{mM})$ under well and deficit irrigation $\left(37.23^{\circ} \mathrm{N}\right.$, $\left.46.16^{\circ} \mathrm{E}\right)$. Foliar spray of compatible organic solutes started from middle vegetative growth and continued till seed filling stage. Comparison of well irrigated and stress conditions revealed that severity of water deficit stress (SI) was 0.25 . Evaluation of growth-related morphological characteristics such as plant height, leaf area, canopy spread and percent ground cover showed that they considerably reduced by water deficit stress. However, foliar application of compatible solutes could somewhat increase growth related parameters. Results showed that water deficit stress noticeably reduced the chlorophyll content, while foliar spray could alleviate the water deficit stress effects when compared with intact plant (non-sprayed plants). The beneficial effect of GB was more prominent than Pr, especially under deficit irrigation condition. Principal component analysis (PCA) indicated that the best performance under well irrigated condition was obtained by application of $4 \mathrm{mM} \mathrm{GB}$ while under deficit irrigation condition the best performance was recorded for plants treated with 2 and $4 \mathrm{mM}$ GB and $20 \mathrm{mM}$ Pr. Overall, results of current experiments showed that foliar spray with high concentration of GB may can significantly alleviate the adverse effects of water deficit stress.

Key words: compatible solutes, foliar spray, osmoregulators, osmotic adjustments, drought tolerance, yield components

Safflower (Carthamus tinctorius L.) is one of the oldest cultivated crops, usually grown at a small scale. Safflower naturally is an oil seed crop but also is grown for flowers used for coloring, flavoring foods, dyes, medicinal properties, and livestock feed (Hussain et al. 2016). Safflower has an acceptable oil profile for straight vegetable oil. Safflower, a strongly tap-rooted annual plant from the family Asteraceae, is native to the Middle East that and it has moderate tolerance to drought (Eslam et al. 2010). Safflower is also a potential biofuel crop but, like sunflower it competes directly with human consumption (Hamanci et al. 2011). Being a relative- ly short-season crop, it fits well into crop rotations. Also, it is a valuable forage for Mediterranean areas since it remains green and has a higher feed value under dry conditions. Safflower is a valuable forage provided it is harvested from mid-budding to early blooming stage (Landau et al. 2004).

Furthermore, safflower is a potential oilseed crop for semi-arid region that is well suited to dryland production. In this regards it is necessary to note that between the different environmental stresses, water deficit is one the main constraint that significantly affect the crop productivity and food security. According to an estimate, one third of the world's

Dr. Mohsen Janmohammadi (*Corresponding author), Eng. Farzaneh Asadi, Dr. Naser Sabaghnia, Dr. Amin Abbasi, Dr. Mojtaba Nouraein, Dr. Fariborz Shekari, Department of Plant Production and Genetic, Agriculture College, University of Maragheh, P.O. Box 55181-83111, Iran. E-mail: jmohamad@alumni.ut.ac.ir 
population live in areas where water is scarce (FAO 2003). Due to population growth and development of economic sectors, the competition for water resources will also grow (Laraus 2004). However, safflower is a neglected oil seed crop in Asian semi-arid regions. It has been used as source of dye, folk medicine and food but it has not got any significant consideration as oil seed crop. The major problems associated with cultivation of this crop are its mechanical harvesting which is quite laborious accompanied by low yields. In the context of increasing demand on crops for food and biofuel production, breeding for drought tolerance holds promises for enhanced yield and extended cultivation seasons.

Compatible solutes are small solutes that are used by cells to maintain cell volume under water stress. They also may involve in scavenging of reactive oxygen species, osmoregulation and stabilization of cell membrane proteins and lipids (Kanwal et al. 2013; Hoang et al. 2016). Some important osmoprotectants are glycinebetaine (GB), trehalose, soluble sugars, proline, etc. (Raza et al. 2017). It is known that plants increase their proline levels under environmental stress. Drought-induced proline accumulation recorded in many plant species has led to the hypothesis that further increases in proline accumulation would improve drought tolerance (Bhaskara et al. 2015). When plants are relieved from the stress, the gathered proline is metabolized to produce reducing agents which maintenance mitochondrial oxidative phosphorylation and generation of ATP, for retrieval and repair of stress-induced modifications (Hare et al. 1999; Wani et al. 2016).

Exogenous proline application as a foliar spray has been demonstrated to decrease the detrimental effects of various abiotic stresses in plants (Ali et al. 2007). Foliar application of proline on two Indian mustard cultivars under mild salinity stress could mitigate the negative effect of salt stress by increasing the antioxidative capacity of the plants (Wani et al. 2016). Exogenous application of proline under stress condition can improve gas exchange parameters, up-regulate stress protective protein expression, reduce lipid peroxidation and increase activities of antioxidant enzymes (Hayat et al. 2012).

Beside, GB is the most well-known quaternary ammonium compounds in higher plants that have critical roles in protection of photosynthesis ma- chinery and ROS detoxification during abiotic stress (Giri 2011). However, at lower concentrations, GB effectively contributes in stabilizing the quaternary structures of enzymes and complex proteins (Chen \& Murata 2008). It has been revealed that exogenous application of GB under drought stress conditions (35\% soil field capacity), on maize plants improved the leaf area, 100 kernels weight biological yield/ plant, grain yield/plant and harvest index (Anjum et al. 2012). However the response to osmoregulators significantly was different between the cultivars. Also the review of the literature indicate that the effect of the osmoregulatores considerably depended on plant species, applied concentration, plant developmental stage, severity of environmental stress and other factors (Dawood 2016).

Water efficiency is a key concept to solve water-shortage problems in semiarid areas. Deficit irrigation in many crops has frequently proved to be an efficient tool to optimize water-use efficiency (Tejero et al. 2011). Under deficit irrigation can save water and also induce plant physiological regulations such as stomatal opening and reproductive and vegetative growth (Du et al. 2015). However, the number of capitula per plant and the number of filled seeds per plant in safflower were shown to be linearly correlated with each other (Eslam et al. 2010). However, the time of drought stress or application of deficit irrigation is very important. To date, little is known about the capacities of compatible organic solutes to cope with water deficit condition and develop drought resistance.

With the above facts in mind, the present work was designed to determine whether foliar application of proline and GB ameliorate the water deficit stress in safflower plants.

\section{MATERIAL AND METHODS}

This study was conducted in the Research Farm of the Faculty of Agriculture, University of Maragheh, Iran (Latitude $37.23^{\circ} \mathrm{N}$, Longitude $46.16^{\circ} \mathrm{E}$, Altitude 1,485 $\mathrm{m}$ above sea level) during the 2014 2015 growing season. The experiment was designed as a split-split plot (using randomized complete block design) with 3 replications. Maragheh is a representative of highland semi-arid zone and, ac- 
cording to the updated classification of Köppen and Geiger, its climate is classified as BSk; cold semi-arid climate with cold winter, temperate spring and hot summer (Peel et al. 2007), with an average annual precipitation of $353 \mathrm{~mm}$, consisting of $73 \%$ of rain and $27 \%$ of snow.

Irrigation regimes (W: well irrigated and S: deficit water stress; treatments was irrigated after 60 , $110 \mathrm{~mm}$ evaporation from class A pan, respectively) were located in main plots and foliar spray compatible solutes (control, 10 and $20 \mathrm{mM}$ of proline and 2 and $4 \mathrm{mM}$ of glycinebetaine) were allocated to sub plots. Glycine betaine (GB; CHEBI: 17750) and L-proline $\left(\mathrm{C}_{5} \mathrm{H}_{9} \mathrm{NO}_{2}\right.$; $\mathrm{CHEBI}$ : 26271) were obtained from Merck (Darmstadt, Germany). The concentrations were selected based on the results of preliminary tests and the results of other studies in the literatures (Ali et al. 2013; Dawood 2016; Janmohammadi et al. 2017). Foliar spray treatments were initiated 40 days after planting and repeated once each 10 days until grain filling stage. Compatible solutes sprayed over the foliage to point of run-off (until every leaf is wetted, but not dripping). Spraying was done by Calibrated backpack sprayer. Considering the similar role of the compounds, the comparison between them and the control was carried out through Fisher's LSD (Least Significant Difference). During the irrigations, the plots were irrigated to up to $70 \%$ of field capacity. Foliar treatment carried out at stem elongation stages and repeated at intervals of fifteen days. Check plants sprayed with distilled water. Experimental fields were ploughed once in early fall and harrowed twice to bring the soil to fine tilth one week before planting. The recommended dose of fertiliser $(100 \mathrm{~kg} \mathrm{~N}$ and $70 \mathrm{~kg}$ $\mathrm{P}_{2} \mathrm{O}_{5} / \mathrm{ha}$ ) was applied in the form of urea and triple superphosphate at the time of seed bed preparation.

A thorn-less variety of safflower, locally referred to as 'Golestan', was used in the present experiment. Before the start of the experiment seed were propagated in isolated fields under full irrigated condition, according to Sabaghnia et al. (2015), in northwest of Iran. Seeds of safflower were treated with $2 \mathrm{~g} / \mathrm{kg}$ Mancozeb and then were sown by hand in $5 \mathrm{~cm}$ depth of soil. The soil type was a clay loam, low in organic carbon $(0.43 \%)$ with a $\mathrm{pH}$ value of 6.85 and total nitrogen and $\mathrm{CaCO}_{3}$ contents of $0.17 \%$ and $19 \%$, respectively. Electrical conductivity (EC) and iron, manganese, copper, zinc, and potassium contents of the soil were measured at $0.84 \mathrm{ds} / \mathrm{m}, 1.62 \mathrm{ppm}$, $6.37 \mathrm{ppm}, 0.49 \mathrm{ppm}, 0.73 \mathrm{ppm}$, and $627 \mathrm{ppm}$, respectively. Safflower seeds planted on 9 April 2015 and harvested at full maturity stage. Each plot included sixteen rows, $4 \mathrm{~m}$ long and $25 \mathrm{~cm}$ apart. Seeds were sown $5 \mathrm{~cm}$ apart at $5 \mathrm{~cm}$ depth. The small terraces of $1 \mathrm{~m}$ in the interspaces was considered to prevent contamination by surface runoff. Plants were thinned to a spacing of $10 \mathrm{~cm}$ within rows 4 weeks after sowing. All plots were irrigated immediately after sowing, and also two irrigations were applied (by $60 \mathrm{~mm}$ evaporation from class A pan) till stem elongation stem then deficit irrigation was carried out for half of plats. During the growing season all plots were irrigated 6 or 7 times and weeded manually. No fungicides were applied.

Chlorophyll index was measured on 10 fully expanded leafs of a plant at each plot using a portable chlorophyll meter (SPAD) at capitulum development stage (BBCH scale: 71; according to Flemmer et al. 2015).

At maturity in July, plants were cut at ground level from two middle rows of plots and then oven dried at $80^{\circ} \mathrm{C}$ until a constant weight. Seeds were separated from straw by crushing. Seed and straw (stem plus leaf) were weighted by a balance and yields were determined per unit of area for different treatments. The total biomass was also determined by summation of safflower seed and straw. Agronomic components of the specified plants were determined after harvest. Yield components were number of capitulum per plant, number of seeds per capitulum, number of branches per plant and 1,000-seeds weight. Harvest index (HI) was calculated according to the following formula: Harvest index $[\%]=($ Grain yield $/$ Biological yield $) \times 100$.

Contents of palmitic acid, arachidic acid and myristic acid were evaluated by gas chromatography according to Rudolphi et al. (2012).

Principal component analysis (PCA) was used to evaluate the behaviors of agronomic traits against to foliar application of compatible organic solutes and drought stress. Data were subjected to One-way ANOVA (analysis of variance) with SAS software (SAS Institute, Cary, NC, USA). Where F tests were significant $(P<0.05)$, means were separated by least significant difference test $(L S D)$. 


\section{RESULTS}

One-way analysis of variance (ANOVA) showed that phenological development affected by irrigation regimes. Plant grown under well irrigated condition had longer vegetative growth and the emergence of capitulum was later than plant under deficit irrigation (Table 1). Foliar spray of compatible solutes, regardless of concentration, postponed the initiation of the reproductive growth. The mean comparison under deficit irrigation showed that the plant treated with GB had a longer vegetative period (Figure 1).

Evaluation of the chlorophyll indicated that both main effects of foliar spray and irrigation levels and also the interaction effect of foliar spray $\times$ irrigation level on chlorophyll concentration was statistically significant at $99 \%$ confidence interval $(P<0.01)$. Deficit irrigation decreased the chlorophyll concentration by $25 \%$ when compared with plants grown under well irrigated condition. The highest chlorophyll concentration was recorded in plants grown under well irrigated condition and treated with 10 $\mathrm{mM}$ proline or $2 \mathrm{mM} \mathrm{GB}$ (Figure 2). Foliar spray with low concentration of compatible solutes considerably improved the chlorophyll concentration under deficit irrigation. Leaf fresh weight noticeably decreased by water shortage by $32 \%$ in comparison with well irrigated plants. Beside, foliar spray of GB could increase the leaf fresh weight and this was more pronounced at high concentrations (Table 1). A similar trend observed for RWC. Assessment of ground cover showed that application deficit irrigation caused a $14 \%$ decrease in ground cover. Foliar spray with proline and GB improved the ground cover, however, the effect of high concentrations of GB was more prominent (28\%).

Evaluation of canopy width showed that both main effects of foliar spray and irrigation levels and also the interaction effect of foliar spray $\times$ irrigation level were significant. The largest canopy width under well irrigated condition was recorded for plants treated with $2 \mathrm{mM} \mathrm{GB}$ while under deficit irrigation condition the best performance obtained by high concentration of GB $(4 \mathrm{mM})$. Assessment of leaf area revealed that deficit irrigation decreased this traits by $37 \%$ in comparison with well irrigated condition. On the other hand, foliar spray of GB at both concentration significantly induced the leaf growth and increased the leaf area. The height of plants grown under favorable moisture conditions considerably was higher than plants under deficit irrigation (by 22\%). Moreover, foliar spray of com-

T a b 1 e 1

Effect of foliar spray of compatible organic solutes on some morphological traits of safflower (Carthamus tinctorius L.) under well-watered and deficit irrigation condition

\begin{tabular}{|c|c|c|c|c|c|c|c|c|}
\hline Irrigation (I) & $\mathrm{DC}$ & CHL & FLW & RWC & $\mathrm{GC}$ & $\mathrm{CW}$ & LA & $\mathrm{PH}$ \\
\hline & ++ & ++ & ++ & ++ & ++ & ++ & ++ & ++ \\
\hline W & $71.13^{\mathrm{a}}$ & $55.24^{\mathrm{a}}$ & $20.24^{\mathrm{a}}$ & $71.20^{\mathrm{a}}$ & $80.13^{\mathrm{a}}$ & $30.13^{\mathrm{a}}$ & $639.50^{\mathrm{a}}$ & $64.61^{\mathrm{a}}$ \\
\hline $\mathrm{S}$ & $54.93^{\mathrm{b}}$ & $41.36^{\mathrm{b}}$ & $13.65^{\mathrm{b}}$ & $60.32^{\mathrm{b}}$ & $69.93^{\mathrm{b}}$ & $18.30^{\mathrm{b}}$ & $423.10^{\mathrm{b}}$ & $50.91^{\mathrm{b}}$ \\
\hline \multicolumn{9}{|c|}{ Foliar spray of compatible organic solutes (F) } \\
\hline & + & ++ & ++ & + & + & + & ++ & + \\
\hline Control & $54.16^{c}$ & $38.49^{c}$ & $10.57^{d}$ & $59.35^{\mathrm{d}}$ & $66.50^{c}$ & $20.21^{b}$ & $483.03^{b}$ & $49.19^{\mathrm{b}}$ \\
\hline $\operatorname{Pr}-10 \mathrm{mM}$ & $64.33^{\mathrm{ab}}$ & $53.37^{\mathrm{a}}$ & $15.35^{\mathrm{c}}$ & $62.55^{\mathrm{c}}$ & $73.00^{\mathrm{b}}$ & $23.31^{\mathrm{ab}}$ & $518.56^{\mathrm{b}}$ & $59.32^{\mathrm{a}}$ \\
\hline $\operatorname{Pr}-20 \mathrm{mM}$ & $61.33^{b}$ & $44.92^{\mathrm{b}}$ & $14.68^{c}$ & $65.36^{b c}$ & $74.33^{\mathrm{b}}$ & $24.06^{\mathrm{ab}}$ & $516.60^{\mathrm{b}}$ & $56.81^{\mathrm{ab}}$ \\
\hline GB-2 mM & $68.00^{\mathrm{a}}$ & $51.64^{\mathrm{b}}$ & $19.74^{b}$ & $68.35^{\mathrm{b}}$ & $76.50^{\mathrm{b}}$ & $26.96^{\mathrm{a}}$ & $569.58^{\mathrm{a}}$ & $58.09^{\mathrm{ab}}$ \\
\hline GB-4 mM & $67.33^{\mathrm{a}}$ & $53.08^{\mathrm{a}}$ & $24.29^{\mathrm{a}}$ & $73.18^{\mathrm{a}}$ & $84.83^{\mathrm{a}}$ & $26.53^{\mathrm{a}}$ & $591.99^{\mathrm{a}}$ & $65.04^{\mathrm{a}}$ \\
\hline $\mathrm{I} \times \mathrm{S}$ & + & ++ & NS & NS & + & + & NS & NS \\
\hline
\end{tabular}

CHL - chlorophyll content [SPAD unit]; DC - number of days to capitulum emergence; FLW - leaves fresh weight [g]; RWC - relative water content; $\mathrm{GC}$ - ground cover [\%]; CW - canopy width [cm]; LA - leaf area $\left[\mathrm{cm}^{2}\right]$; $\mathrm{PH}$ - plant height at maturity [cm]; W - well-watered; S - deficit irrigation; Pr - proline; GB - glycinebetaine; NS - Not significant; ${ }^{+}-$Significant at $5 \%$ level of probability, ${ }^{++}$- Significant at $1 \%$ level of probability. Mean values of the same category followed by different letters are significant at $P \leq 0.05$ level. 
patible solutes induced the plant elongation and the tallest plants obtained by foliar application of $4 \mathrm{mM}$ GB (Table 1).

Assessment of biological yield showed that the highest value was obtained for plant grown under well irrigated condition along with foliar application GB while the lowest amount was recorded for plants grown under deficit irrigation without foliar treatment or treated with $20 \mathrm{mM}$ proline (Table 2). Application of GB in both moisture regimes could improve the biological yield.

Both main effects of foliar spray and irrigation levels and also the interaction effect of foliar spray $x$ irrigation level were significant on capitulum diameter $(P<0.05)$. The largest capitulum was recorded in plant grown under well irrigated condition with foliar application of $10 \mathrm{mM}$ proline or $2 \mathrm{mM} \mathrm{GB}$ (Figure 3). Interestingly, the low concentration of both compatible solutes could significantly increase capitulum diameter under deficit irrigation. Number of the capitulum per plant was not affected by foliar treatments. However, water shortage reduced the number of the capitulum by $24 \%$ in comparison with well irrigated plants (Table 2).

Evaluation of seed weight showed that the interaction effect of foliar spray $\times$ irrigation level were significant on this trait $(P<0.05)$. The effect of compatible solutes on seed weight under well irrigated condition was more prominent than deficit irrigation condition. The highest seed weight was recorded for plants grown under well irrigated condition and treated with GB. Seed number per capitulum as one of the most important yield component considerably affected $(P<0.01)$ by irrigation level so that water shortage decreased this trait by $25 \%$ when compared with well irrigated condition.

Furthermore, foliar treatment significantly affected the seed number per capitulum and the highest number was recorded for plant treated with GB or high concentration of proline (Table 2). Assessment of seed yield revealed that interaction effect of foliar spray $\times$ irrigation level were significant on this trait $(P<0.05)$. Mean comparison of seed yield between combined treatments showed that the highest value

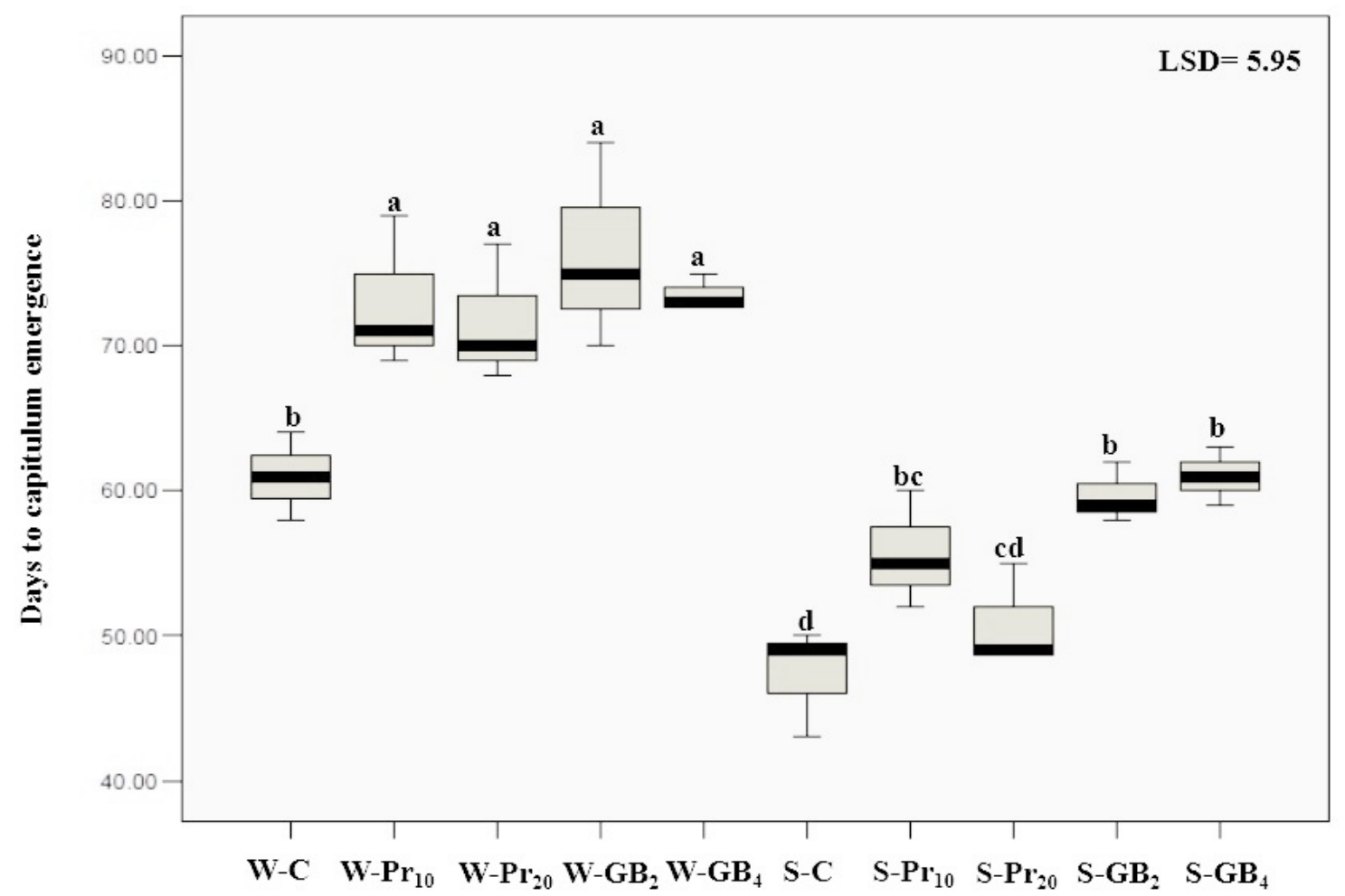

Figure 1. The effects of foliar spray of proline and glycinebetaine on phenological development of safflower under well irrigated (W) and deficit irrigation (S) condition. C - control plants that treated with distilled water; $\operatorname{Pr}-\operatorname{proline}$; GB glycinebetaine. The numbers along with the compatible compounds refer to the applied concentrations (mM). Different letters within columns indicate statistically significant differences $(P<0.05)$. 
$\mathrm{T}$ a

Impact of foliar spray of proline and glycinebetaine on some yield components of safflower (Carthamus tinctorius L.) under well-watered and deficit irrigation condition

\begin{tabular}{|c|c|c|c|c|c|c|c|}
\hline Irrigation (I) & $\mathrm{BY}$ & $\mathrm{CD}$ & CNP & TSW & SNC & SY & HI \\
\hline & ++ & + & + & ++ & ++ & ++ & ++ \\
\hline $\mathrm{W}$ & $5,159^{\mathrm{a}}$ & $28.33^{\mathrm{a}}$ & $9.36^{\mathrm{a}}$ & $35.87^{\mathrm{a}}$ & $28.79^{\mathrm{a}}$ & $1,136.41^{\mathrm{a}}$ & $24.37^{\mathrm{a}}$ \\
\hline S & $3,648^{\mathrm{b}}$ & $24.05^{\mathrm{b}}$ & $7.12^{\mathrm{b}}$ & $30.73^{\mathrm{b}}$ & $21.57^{\mathrm{b}}$ & $883.95^{\mathrm{b}}$ & $22.10^{\mathrm{b}}$ \\
\hline \multicolumn{8}{|c|}{ Foliar spray of compatible organic solutes $(\mathrm{F})$} \\
\hline & ++ & + & NS & + & + & + & NS \\
\hline Control & $4,154^{\mathrm{c}}$ & $23.66^{\mathrm{c}}$ & $7.33^{\mathrm{b}}$ & $31.55^{\mathrm{c}}$ & $22.99^{c}$ & $946.50^{c}$ & $23.17^{\mathrm{a}}$ \\
\hline $\operatorname{Pr}-10 \mathrm{mM}$ & $4,363^{\mathrm{bc}}$ & $31.68^{\mathrm{a}}$ & $7.90^{\mathrm{ab}}$ & $33.03^{\mathrm{bc}}$ & $23.80^{\mathrm{bc}}$ & $996.34^{b c}$ & $23.04^{\mathrm{a}}$ \\
\hline $\operatorname{Pr}-20 \mathrm{mM}$ & $4,185^{\mathrm{c}}$ & $25.77^{\mathrm{bc}}$ & $7.50^{\mathrm{b}}$ & $32.84^{\mathrm{b}}$ & $25.42^{\mathrm{abc}}$ & $976.78^{b c}$ & $23.68^{\mathrm{a}}$ \\
\hline GB-2 mM & $4,556^{\mathrm{ab}}$ & $30.22^{\mathrm{ab}}$ & $9.16^{\mathrm{a}}$ & $34.05^{\mathrm{ab}}$ & $25.92^{\mathrm{ab}}$ & $1,011.73^{b}$ & $22.45^{\mathrm{a}}$ \\
\hline GB-4 mM & $4,758^{\mathrm{a}}$ & $25.63^{\mathrm{bc}}$ & $9.33^{\mathrm{a}}$ & $35.01^{\mathrm{a}}$ & $27.76^{\mathrm{a}}$ & $1,119.55^{\mathrm{a}}$ & $23.81^{\mathrm{a}}$ \\
\hline $\mathrm{I} \times \mathrm{S}$ & + & + & NS & + & NS & + & NS \\
\hline
\end{tabular}

$\mathrm{BY}$ - biological yield [kg/ha]; CD - capitulum diameters [mm]; CNP - capitulum numbers per plants; TSW - 1,000-seeds weight [g]; SNC - seed number per capitulum; SY - seed yield [kg/ha]; HI: harvest index [\%]. W - well-watered; S - deficit irrigation; $\mathrm{Pr}$ - proline; GB - glycinebetaine; NS - Not significant; ${ }^{+}-$Significant at $5 \%$ level of probability; ${ }^{++}$- Significant at $1 \%$ level of probability. Mean values of the same category followed by different letters are significant at $P \leq 0.05$ level.

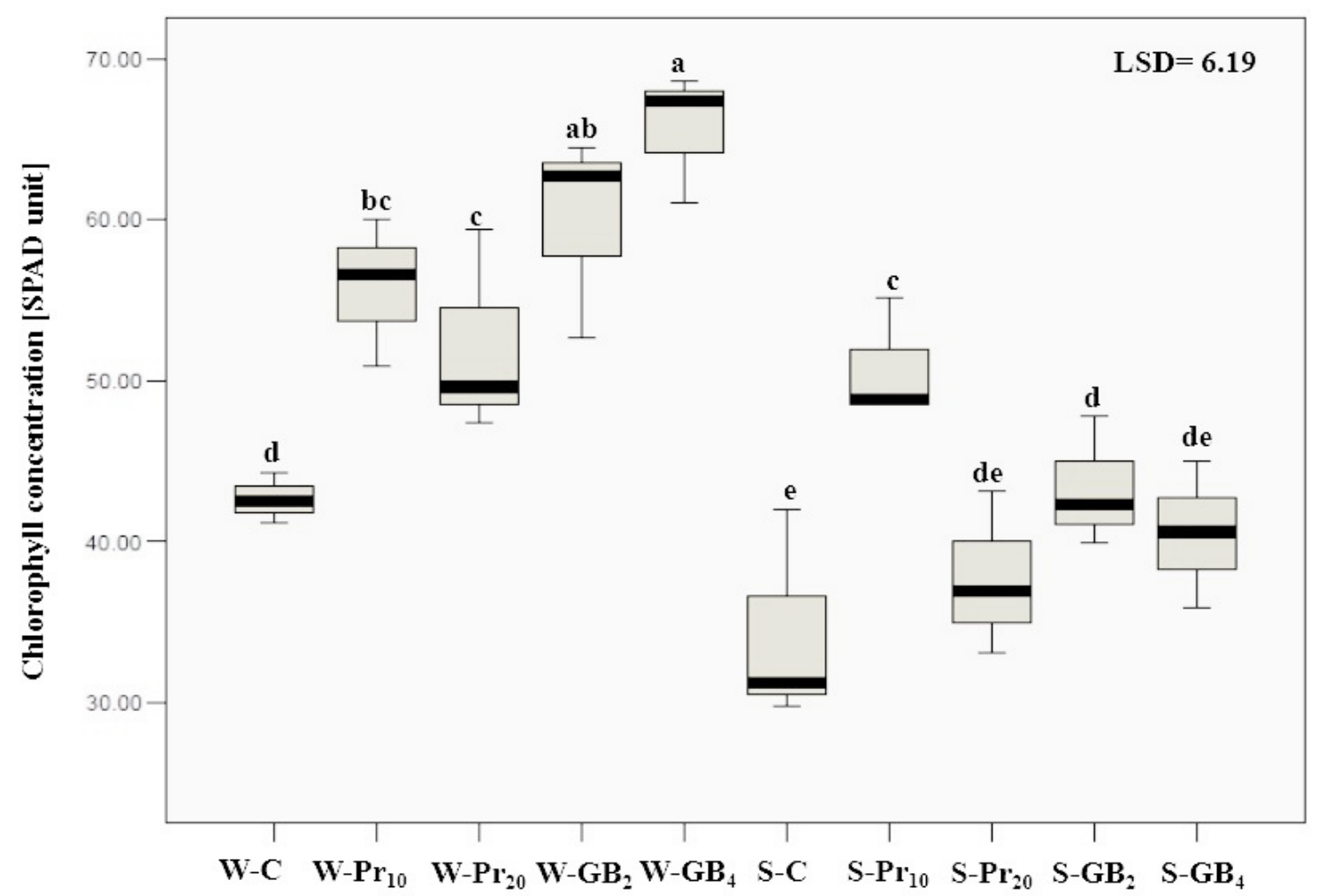

Figure 2. Impacts of foliar spray of compatible organic solutes (proline and glycinebetaine) on chlorophyll concentration of safflower under well irrigated (W) and deficit irrigation (S) condition. C - control plants that treated with distilled water; $\mathrm{Pr}$ - proline; GB - glycinebetaine. 
patible solutes induced the plant elongation and the tallest plants obtained by foliar application of $4 \mathrm{mM}$ GB (Table 1).

Assessment of biological yield showed that the highest value was obtained for plant grown under well irrigated condition along with foliar application GB while the lowest amount was recorded for plants grown under deficit irrigation without foliar treatment or treated with $20 \mathrm{mM}$ proline (Table 2). Application of GB in both moisture regimes could improve the biological yield.

Both main effects of foliar spray and irrigation levels and also the interaction effect of foliar spray $x$ irrigation level were significant on capitulum diameter $(P<0.05)$. The largest capitulum was recorded in plant grown under well irrigated condition with foliar application of $10 \mathrm{mM}$ proline or $2 \mathrm{mM} \mathrm{GB}$ (Figure 3). Interestingly, the low concentration of both compatible solutes could significantly increase capitulum diameter under deficit irrigation. Number of the capitulum per plant was not affected by foliar treatments. However, water shortage reduced the number of the capitulum by $24 \%$ in comparison with well irrigated plants (Table 2).

Evaluation of seed weight showed that the interaction effect of foliar spray $\times$ irrigation level were significant on this trait $(P<0.05)$. The effect of compatible solutes on seed weight under well irrigated condition was more prominent than deficit irrigation condition. The highest seed weight was recorded for plants grown under well irrigated condition and treated with GB. Seed number per capitulum as one of the most important yield component considerably affected $(P<0.01)$ by irrigation level so that water shortage decreased this trait by $25 \%$ when compared with well irrigated condition.

Furthermore, foliar treatment significantly affected the seed number per capitulum and the highest number was recorded for plant treated with GB or high concentration of proline (Table 2). Assessment of seed yield revealed that interaction effect of foliar spray $\times$ irrigation level were significant on this trait $(P<0.05)$. Mean comparison of seed yield between combined treatments showed that the highest value was recorded for plant grown under well irrigated condition and treated with $4 \mathrm{mM}$ GB. Remarkably, differences between other compatible solutes in well irrigated conditions were not significant. Utilization of high concentrations of GB under deficit irrigation conditions had more promising effects (Figure 4).

Evaluation of fatty acid profile in safflower oil showed that the interaction effect of foliar spray $x$ irrigation level were significant on content of palmitic acid, arachidic acid and myristic acid $(P<0.05)$. The content of palmitic acid and arachidic acid significantly reduced by water shortage (Table 3 ). Mean comparision for palmitic acid showed that although foliar application of compatible solutes increased the palmitic acid content, the highest amount was recorded in plants grown under irrigated condition and treated with $4 \mathrm{mM} \mathrm{GB}$ (Table 3). The effects of foliar spray under well irrigated condition was more prominent than deficit irrigation condition. The highest content of arachidic acid recorded for plants grown under well irrigated condition and sprayed with proline while the highest content under deficit irrigation was obtained by foliar spray of $4 \mathrm{mM}$ GB. The content of myristic acid less affected by water shortage compared to other fatty acids. Under both irrigation level the highest content of myristic acid was recorded for plant treated with $4 \mathrm{mM} \mathrm{GB}$ (Table $3)$.

Principal component analysis (PCA) was employed to provide an overview of the capacity to distinguish combined treatments. First principal component clearly separated the irrigation levels (Figure 5). PCA could separate the foliar treatments by second component. PCA evidently separated the high concentration of proline and both concentrations of GB from other treatments under deficit irrigation. Also second principal component segregated the $4 \mathrm{mM}$ GB from other treatment under well irrigated condition (Figure 5). Correlation between all possible characters are presented in Table 4. Correlations between seed yield and chlorophyll concentration, relative water content (RWC), ground cover, canopy width, leaf area, capitulum diameter, seed number per capitulum and 1,000-seed weight were positive and significant. High correlation between seed yield and RWC refers to the importance of water status in semi-arid conditions. A positive significant correlation observed between seed number per capitulum (SNC) and canopy growth parameter (canopy width, ground cover, leaf area). Also there was a positive correlation between SNC and number of the days to capitulum emergence (Table 4). 
$\mathrm{T}$ a

Effect of foliar spray of proline and glycinebetaine on fatty acids content of safflower (Carthamus tinctorius L.) under well-watered and deficit irrigation condition

\begin{tabular}{|c|c|c|c|}
\hline Combined treatments & Palmitic acid & Arachidic acid & Myristic acid \\
\hline W-Control & $8.17^{\mathrm{c}}$ & $0.35^{\mathrm{c}}$ & $0.24^{\mathrm{d}}$ \\
W-Pr-10 mM & $9.04^{\mathrm{bc}}$ & $0.43^{\mathrm{ab}}$ & $0.293^{\mathrm{c}}$ \\
W-Pr-20 mM & $9.17^{\mathrm{b}}$ & $0.576^{\mathrm{a}}$ & $0.316^{\mathrm{bc}}$ \\
W-GB-2 $\mathrm{mM}$ & $9.75^{\mathrm{b}}$ & $0.286^{\mathrm{d}}$ & $0.263^{\mathrm{d}}$ \\
W-GB-4 mM & $10.86^{\mathrm{a}}$ & $0.413^{\mathrm{b}}$ & $0.459^{\mathrm{a}}$ \\
S-Control & 6.46 & $0.176^{\mathrm{ef}}$ & $0.156^{\mathrm{ef}}$ \\
S-Pr-10 mM & $6.97^{\mathrm{de}}$ & $0.196^{\mathrm{e}}$ & $0.273^{\mathrm{cd}}$ \\
S-Pr-20 mM & $7.44^{\mathrm{d}}$ & $0.29^{\mathrm{d}}$ & $0.196^{\mathrm{e}}$ \\
S-GB-2 mM & $7.6^{\mathrm{cd}}$ & $0.23^{\mathrm{d}}$ & $0.30^{\mathrm{c}}$ \\
S-GB-4 mM & $8.24^{\mathrm{c}}$ & $0.303^{\mathrm{c}}$ & $0.396^{\mathrm{b}}$ \\
\hline
\end{tabular}

W - well irrigated and deficit irrigation (S) condition; C - control plants that treated with distilled water; $\mathrm{Pr}-\mathrm{proline}$; B - glycinebetaine. The numbers along with the compatible compounds refer to the applied concentrations (mM). Different letters within columns indicate statistically significant differences $(P<0.05)$.

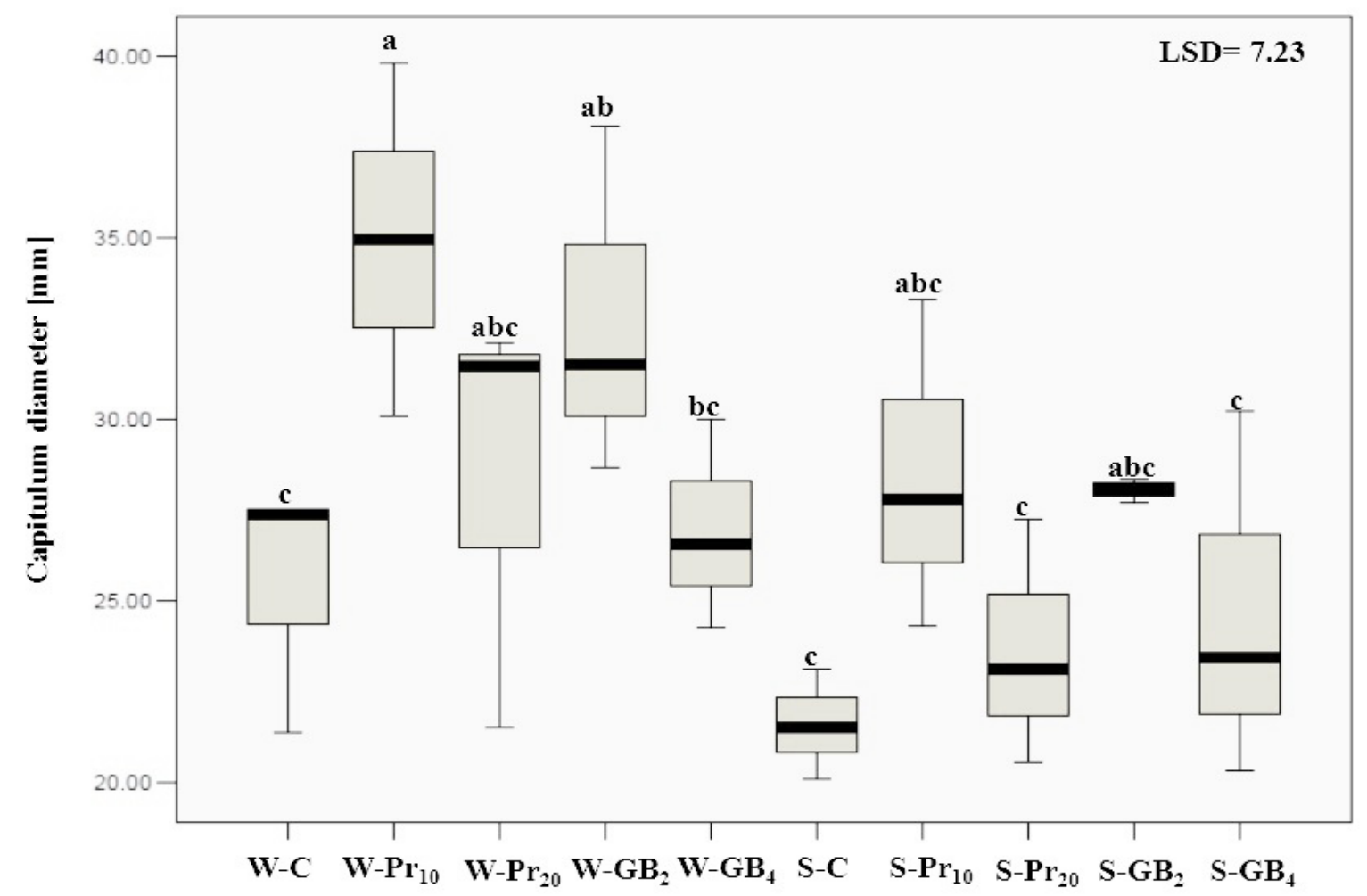

Figure 3. The effects of foliar spry of proline and glycinebetaine on capitulum diameter safflower under well irrigated (W) and deficit irrigation (S) condition. $\mathrm{C}$ - control plants that treated with distilled water; Pro - proline, GB - glycinebetaine. 
T a b

Correlation coefficient for morphological and agronomical traits of Safflower (Carthamus tinctorius L.) under different irrigation level and foliar treatments

\begin{tabular}{|l|c|c|c|c|c|c|c|c|c|c|c|c|c|c|}
\hline & CHL & DC & FLW & RWC & GC & CW & LA & PH & BY & CD & CNP & HSW & SNC & SY \\
\hline DC & $0.88^{++}$ & & & & & & & & & & & & & \\
FLW & $0.82^{+}$ & $0.83^{+}$ & & & & & & & & & & & \\
RWC & $0.71^{+}$ & $0.92^{++}$ & $0.93^{++}$ & & & & & & & & & & & \\
GC & $0.77^{+}$ & $0.88^{++}$ & $0.74^{+}$ & $0.97^{++}$ & & & & & & & & & \\
CW & $0.87^{+}$ & $0.96^{++}$ & 0.60 & $0.91^{++}$ & $0.92^{++}$ & & & & & & & & & \\
LA & $0.83^{+}$ & $0.94^{++}$ & $0.71^{+}$ & $0.92^{++}$ & $0.85^{+}$ & $0.97^{++}$ & & & & & & & & \\
PH & 0.59 & $0.91^{++}$ & 0.46 & 0.60 & $0.73^{++}$ & 0.56 & 0.59 & & & & & & \\
BY & $0.85^{+}$ & $0.72^{+}$ & $0.77^{+}$ & $0.88^{++}$ & $0.81^{+}$ & $0.96^{++}$ & $0.99^{++}$ & $0.84^{+}$ & & & & & \\
CD & $0.72^{+}$ & $0.77^{+}$ & 0.47 & 0.49 & 0.47 & 0.45 & 0.61 & 0.65 & 0.59 & & & & \\
CNP & 0.55 & 0.53 & 0.56 & $0.86^{++}$ & $0.86^{++}$ & $0.71^{+}$ & $0.77^{+}$ & $0.81^{+}$ & $0.72^{+}$ & $0.79^{+}$ & & & \\
HSW & $0.89^{++}$ & $0.95^{++}$ & $0.76^{+}$ & $0.92^{++}$ & $0.86^{++}$ & $0.71^{+}$ & $0.98^{++}$ & $0.90^{++}$ & $0.97^{++}$ & 0.61 & $0.78^{+}$ & & \\
SNC & $0.76^{+}$ & $0.90^{++}$ & 0.63 & $0.93^{++}$ & $0.87^{++}$ & $0.93^{+}$ & $0.97^{++}$ & 0.62 & $0.94^{++}$ & 0.52 & 0.68 & $0.96^{++}$ & \\
SY & $0.82^{+}$ & 0.60 & 0.63 & $0.92^{++}$ & $0.89^{++}$ & $0.82^{+}$ & $0.78^{+}$ & 0.59 & $0.97^{++}$ & $0.73^{+}$ & $0.79^{+}$ & $0.96^{++}$ & $0.96^{++}$ & \\
HI & -0.43 & $-0.76^{+}$ & -0.44 & -0.58 & -0.45 & $-0.83^{+}$ & -0.58 & -0.50 & $-0.84^{+}$ & -0.63 & -0.38 & $-0.76^{+}$ & -0.65 & $-0.70^{+}$ \\
\hline
\end{tabular}

CHL - chlorophyll content; DC - number of days to capitulum emergence; FLW - leaves fresh weight; RWC - relative water content; GC - ground cover; CW - canopy width; LA - leaf area; PH - plant height at maturity; BY - biological yield; CD - capitulum diameters; CNP - capitulum numbers per plants; TSW - 1,000-seeds weight; SNC - seed number per capitulum; SY - seed yield; HI - harvest index. ${ }^{+},{ }^{++}$Significant at the 0.05 and 0.01 probability levels, respectively.

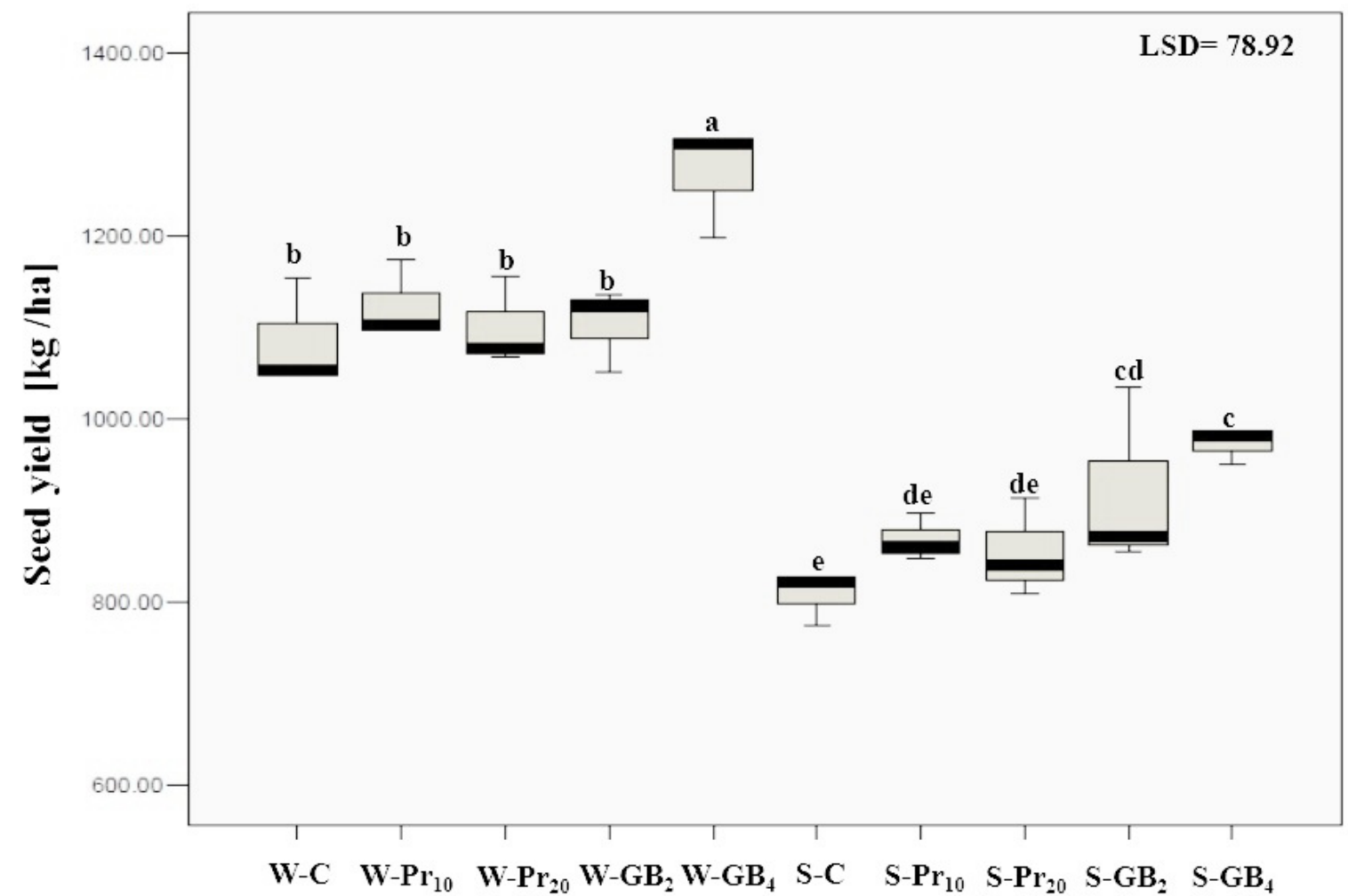

Figure 4. Seed yield of safflower affected by foliar spray of compatible organic solutes (proline and glycinebetaine). C control plants that treated with distilled water; $\mathrm{Pr}$ - proline; GB - glycinebetaine. The numbers along with the compatible compounds refer to the applied concentrations (mM). Different letters within columns indicate statistically significant differences $(P<0.05)$. 
In addition cluster analysis was used for categorizing the evaluated traits according to the similarities in change trends (Figure 6). Cluster analysis could divided the all evaluated traits in four group. Group I included trait such as chlorophyll concentration, days to capitulum emergence, canopy width, 1,000-seed weight, leaf area, biological yield, seed yield and number of the capitulum per plant. In this cluster the best performance was obtained by application of GB. However application of low concentration of proline under deficit irrigation could improve the mentioned traits. Group II included harvest index, seed number per plants, RWC, ground cover and plant height that showed the best performance by application of $4 \mathrm{mM} \mathrm{GB}$. Group III included traits such as capitulum diameter that the best performance was recorded by application of low concentration proline or GB. Group IV included leaf fresh weight that induced by both compatible solutes. However the effects of GB application was more prominent.

\section{DISCUSSION}

In the changing climate, plants are constantly exposed to abiotic stress, such as drought, which is one of the most serious problems associated with plant growth and development affecting agricultural demands (Overpeck \& Cole 2006). When plants are subjected to environmental stress may show a wide range of behaviors or strategies of coping, and accordingly them can be divided from very sustainable to high tolerant. Although drought resistance is largely controlled by plant genetics, it appears that some agronomic strategies can also improve plant resistance to environmental stress (Raza et al. 2017). The results of present study revealed that in general, deficit irrigation (irrigation after $60 \mathrm{~mm}$ evaporation) applied at vegetative and reproductive growth had strong negative effects on the growth safflower plants. The main objective of deficit irrigation is to increase the water use efficiency (WUE) of a crop by eliminating irrigations that have little

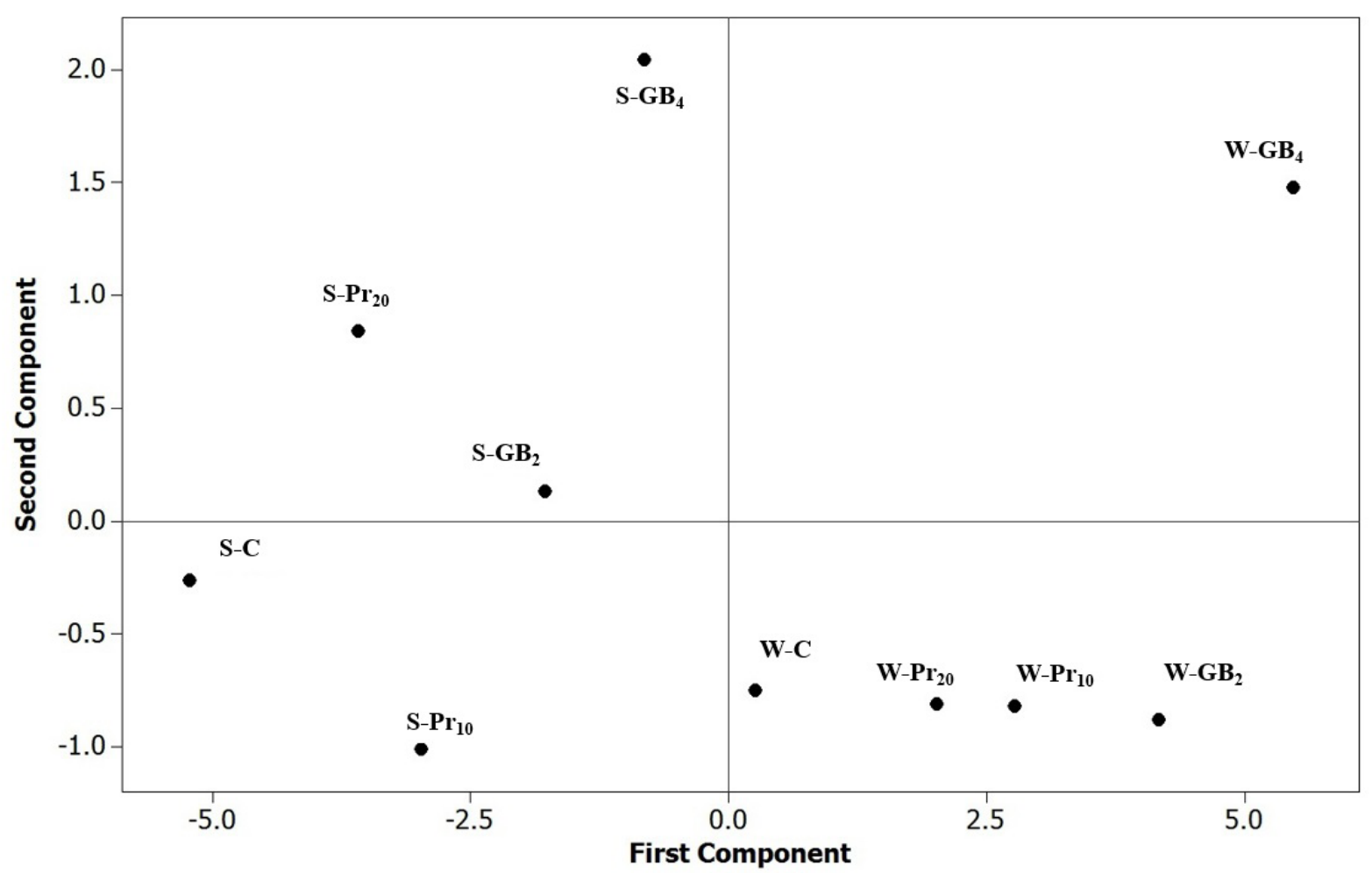

Figure 5. Bi-plot of the first two principal components (PC1 and PC2) for combined treatments of foliar spray of compatible solutes and irrigation levels. $\mathrm{W}-$ well irrigated and $\mathrm{S}-$ deficit irrigation; $\mathrm{C}-$ control plants that treated with distilled water, $\mathrm{Pr}-\operatorname{proline}$; $\mathrm{GB}$ - glycinebetaine. The numbers along with the compatible compounds refer to the applied concentrations (mM). 
impact on yield. The resulting yield reduction may be small compared with the benefits gained through diverting the saved water to irrigate other crops for which water would normally be insufficient under traditional irrigation practices. However, due to the severe shortage of water in the northwest of Iran, high water prices, the lack of adequate water distribution structures, the lack of proper and the lack of proper irrigation planning to distribute available water between crops during the spring deficit irrigation should continue to be considered as a solution. It can also be associated with other agronomic measures such as varying tillage practices, mulching and anti-transpirants that reduce the demand for irrigation water. It seems with eliminating some irrigation during the vegetative and increasing the amount of water supply at reproductive stage partially can improve the seed yield.

Altogether, application of long-term deficit irrigation can change the sink-source relationship and allocation of nutrients. Under long-term exposure to water deficit conditions both sink and source size reduced and this is interpretable by reduced the canopy size and decreased the yield components. On the other hand, a significant decrease in chlorophyll content of leaves can have a negative effect on the activity of the source. However, our result showed that foliar application of compatible organic solute improved plant sink-source relationship and water statue and RWC. Reduction in relative water content (RWC) and leaf water potential caused decrease in photosynthesis of higher plants (Lawlor \& Cornic 2002). In accordance to these results, Blum (1996) and Shahbaz et al. (2012) concluded that osmolytes accumulation in plant cells results in a decrease of the cell osmotic potential and thus in maintenance of water absorption and cell turgor pressure, which might contribute to sustain physiological processes, such as stomatal opening, photosynthesis, and growth expansion. These results were in a good conformity with those obtained by Aldesuquy et al. (2013) who reported that foliar application of

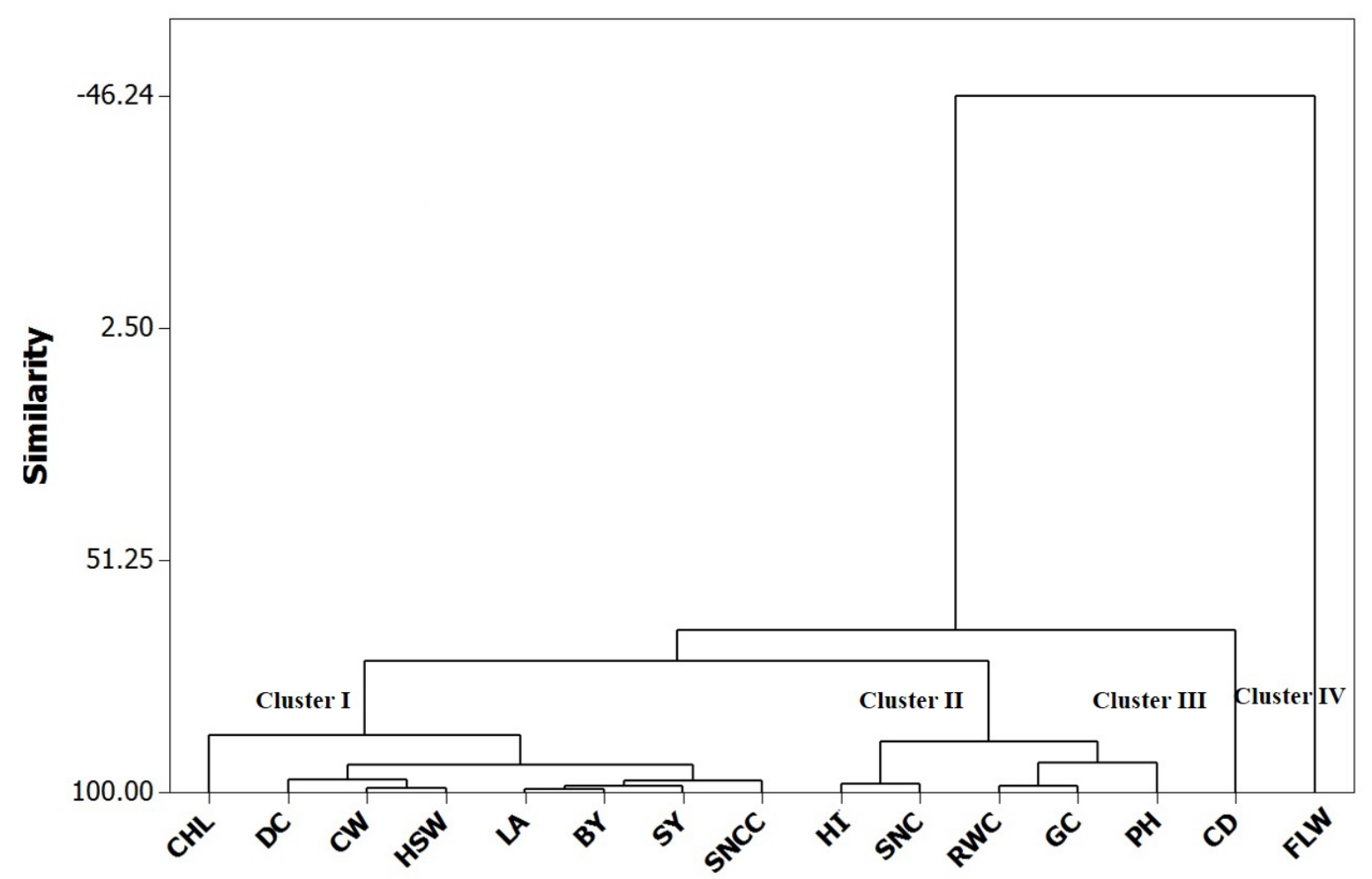

Figure 6. Cluster analysis of agronomic traits of Safflower (Carthamus tinctorius L.) grown in highland semi-arid region of Maragheh. CHL - chlorophyll concentration; DC - days to capitulum emergence; HSW - 1,000-seeds weight; LA - leaf area; BY - biological yield; SY - seed yield; SNCC - seed number per capitulum; HI - harvest index; SNC - percentage of unfilled seeds; RWC - relative water content; GC - ground cover; PH - plant height; CD - capitulum diameter; FLW - leaves fresh weigh. 
compatible solute appeared to mitigate the effect of water stress on wheat yield and the effect was more pronounced with $(\mathrm{GB}+$ salicylic acid) treatment. This improvement would result from the beneficial effect of the provided chemicals on growth and metabolism of wheat plants under water deficit conditions. This finding also is in agreement with Iqbal et al. (2008) findings which showed that foliar application of GB at the vegetative or reproductive growth stage, however, increased leaf water and turgor potentials to some extent in both sunflower lines when grown under water stress.

Beside, another important finding was a strong correlation between seed number per capitulum and canopy width. This finding is in agreement with our previous finding (Janmohammadi et al. 2014) which showed some foliar treatment can accelerate the canopy growth and ground covering and then significantly reduce the evaporation for soil surface. The maintenance of soil moisture can support seed yield production in the end stages.

Amino acid profiling revealed that deficit irrigation negatively affect the amount of palmitic acid and arachidic acid, however, the foliar application of compatible organic solutes had significant ameliorative effect. However, the findings of the current study do not support the previous research where the foliar application of GB and proline could not increase the oil content in sunflower seeds (Janmohammadi et al. 2017). This may be due to the concentration used or the poor response of sunflower as a plant species. The results of the present study are consistent with those of Hussain et al. (2009), who found that exogenous application of GB and salicylic acid improved oil content of sunflower (Helianthus annuus L.) under different irrigation regimes.

Although the best performance was obtained by GB application, proline was also useful in some cases especially under deficit irrigation condition. In this regards, Ali et al. (2013) reported that exogenous application of proline has ameliorating effects of on seed composition, seed oil quality and oil antioxidant activity of maize (Zea mays L.) under drought stress. The concentrations of antioxidant compounds namely phenolics, carotenoids, flavonoids and tocopherols estimated in the seed oil increased due to foliar-applied proline under water deficit conditions that was positively correlated with the enhanced free radical scavenging activity. It has been revealed that exogenous application of proline can induce stress tolerance by maintaining cell turgor or osmotic balance; stabilizing membranes thereby preventing electrolyte leakage; and bringing concentrations of reactive oxygen species within normal ranges, thus preventing oxidative burst in plants (Hayat et al. 2012). However, the low efficacy of proline in comparison to GB can be attributed to applied concentrations.

Although drought-stressed plants accumulate various compatible molecules such as proline, GB etc., our result showed that foliar application of GB significantly mitigate the negative effects of drought stress. This may be due to this reason that the accumulation of a compatible solute is an energy-consuming process in addition to the already existing metabolic costs. These findings further support the previous researches that revealed the positive effects of exogenous application of GB on plant growth and final crop yield under drought stress in different plants such as tobacco, wheat, barley, sorghum, soya bean and common beans (reviewed by Ashraf \& Follad 2007).

\section{CONCLUSIONS}

Results revealed that applied deficit irrigation, cannot be a suitable method to save water and improving the water use efficiency. Water deficit significantly decreased the canopy growth, leaf area and yield components. However foliar application of glycinebetaine and proline especially in high concentration could mitigate the negative effects of water deficit stress. Foliar application of glycinebetaine much more effective than proline. Foliar application high concentration proline showed some ameliorative effect under water deficit stress. Among the evaluated traits a positive significant correlation was recorded between seed yield and RWC. Hence the study of plant water statue can be introduced as valuable marker for evaluating the efficiency of spraying treatments.

Acknowledgments. This work was funded by University of Maragheh and the Ministry of Science, Research and Technology of Iran. The authors 
express their deepest gratitude to S. Soltani and A. Ezati for their contribution to field experiment. They also thank A. Ebadi for his advice on English corrections to paper.

\section{REFERENCES}

ALDESUQUY, H.S. - ABBAS, M.A. - ABO-HAMED, S.A. ELHAKEM, A.H. 2013. Does glycine betaine and salicylic acid ameliorate the negative effect of drought on wheat by regulating osmotic adjustment through solutes accumulation? In Journal of Stress Physiology \& Biochemistry, vol. 9, no. 3, pp. 5-22. DOI: 10.1177/0741713611402046

ALI, Q. - ANWAR, F. - ASHRAF, M. - SAARI, N. - PERVEEN, R. 2013. Ameliorating effects of exogenously applied proline on seed composition, seed oil quality and oil antioxidant activity of maize (Zea mays L.) under drought stress. In International Journal of Molecular Sciences, vol. 14, no.1, pp. 818-835. DOI: 10.3390/ijms 14010818

ANJUM, S.A. - SALEEM, M.F. - WANG, L.C. - BILAL, M.F. - SAEED, A. 2012. Protective role of glycinebetaine in maize against drought-induced lipid peroxidation by enhancing capacity of antioxidative system. In Australian Journal of Crop Science, vol. 6, no. 4, pp. 576-583. DOI: ielhss;dn/260696456888352

ASHRAF, M. - FOOLAD, M. 2007. Roles of glycine betaine and proline in improving plant abiotic stress resistance. In Environmental and Experimental Botany, vol. 59, no. 2, pp. 206-216. DOI: 10.1016/j.envexpbot.2005.12.006

BHASKARA, G.B. - YANG, T.H. - VERSLUES, P.E. 2015. Dynamic proline metabolism: importance and regulation in water limited environments. In Frontiers in Plant Science, vol. 6. DOI: $10.3389 /$ fpls.2015.00484

BLUM, A. 1996. Crop responses to drought and the interpretation of adaptation. In Plant Growth Regulation, vol. 20, no. 2, pp. 135-148. DOI: $10.1007 / \mathrm{BF} 00024010$

CHEN, T.H. - MURATA, N. 2008. Glycinebetaine: an effective protectant against abiotic stress in plants. In Trends in Plant Science, vol. 13, no. 9, pp. 499-505. DOI: 10.1016/j. tplants.2008.06.007

DAWOOD, M.J. 2016. Influence of osmoregulators on plant tolerance to water stress. In Scientia Agricola, vol. 13, no. 1, pp. 42-58.

DU, T. - KANG, S. - ZHANG, J. - DAVIES, W.J. 2015. Deficit irrigation and sustainable water-resource strategies in agriculture for China's food security. In Journal of Experimental Botany, vol. 66, no. 8, pp. 2253-2269. DOI: 10.1093/ jxb/erv034

ESLAM, B.P. - MONIRIFAR, H. - GHASSEMI, M.T. 2010. Evaluation of late season drought effects on seed and oil yields in spring safflower genotypes. In Turkish Journal of Agriculture and Forestry, vol. 34, no. 5, pp. 373-380. DOI: ajcs.2012.72.79

FAO, 2003. Unlocking the water potential of agriculture. Food and Agriculture Organization, United Nation, Rome. www. fao.org/docrep/006/y $4525 \mathrm{e} / \mathrm{y} 4525 \mathrm{e} 00$.

FLEMMER, A.C. - FRANCHINI, M.C. - LINDSTRÖM, L.I. 2015. Description of safflower (Carthamus tinctorius) phenological growth stages according to the extended BBCH scale. In Annals of Applied Biology, vol. 166, no. 2, pp. 331-339. DOI: 10.1111/aab.12186

GIRI, J. 2011. Glycinebetaine and abiotic stress tolerance in plants. In Plant signaling \& behavior, vol. 6 , no. 11, pp. 1746-1751. DOI: $10.4161 /$ psb.6.11.17801
HAMAMCI, C. - SAYDUT, A. - TONBUL, Y. - KAYA, C. - KAFADAR, A.B. 2011. Biodiesel production via transesterification from safflower (Carthamus tinctorius L.) seed oil. In Energy Sources, Part A: Recovery, Utilization, and Environmental Effects, vol. 33, no. 6, pp. 512-520. DOI: 10.1080/15567030903096964

HARE, P.D. - CRESS, W.A. - Van STADEN, J. 1999. Proline synthesis and degradation: a model system for elucidating stress-related signal transduction. In Journal of Experimental Botany, vol. 50, no. 333, pp. 413-434. DOI: https://doi. org $/ 10.1093 / \mathrm{jxb} / 50.333 .413$

HAYAT, S. - HAYAT, Q. - ALYEMENI, M.N. - WANI, A.S. - PICHTEL, J. - AHMAD, A. 2012. Role of proline under changing environments: a review. In Plant Signaling \& Behavior, vol. 7, no. 11, pp.1456-1466. DOI: 10.4161/ psb. 21949

HOANG, T.M.L. - TRAN, T.N. - NGUYEN, T.K.T. - WILLIAMS, B. - WURM, P. - BELLAIRS, S. - MUNDREE, S. 2016. Improvement of salinity stress tolerance in rice: challenges and opportunities. In Agronomy, vol. 6, no. 4, pp. 54. DOI: 10.3390 /agronomy 6040054

HUSSAIN, M.I. - LYRA, D.A. - FAROOQ, M. - NIKOLOUDAKIS, N. - KHALID, N. 2016. Salt and drought stresses in safflower: a review. In Agronomy for sustainable development, vol. 36, no. 1, pp. 1-31. DOI: 10.1007/s13593-0150344-8

IQBAL, N. - ASHRAF, M. - ASHRAF, M.Y. 2008. Glycinebetaine, an osmolyte of interest to improve water stress tolerance in sunflower (Helianthus annuus L.): water relations and yield. In South African Journal of Botany, vol. 74, no. 2, pp. 274-281. DOI: 10.1016/j.sajb.2007.11.016

JANMOHAMMADI, M. - NASIRI, Y. - ZANDI, H. KOR-ABDALI, M. - SABAGHNIA, N. 2014. Effect of manure and foliar application of growth regulators on lentil (Lens culinaris) performance in semi-arid highland environment. In Botanica Lithuanica, vol. 20, no. 2, pp. 99-108. DOI: $10.3923 /$ pjbs.2013.51.58

JANMOHAMMADI, M. - YOUSEFZADEH, S. - DASHTI, S. - SABAGHNIA, N. 2017. Effects of exogenous application of nano particles and compatible organic solutes on sunflower (Helianthus annuus L.). In Botanic Serbica, vol. 14 , no. 2 , pp. 37-46. DOI: 10.5281 /zenodo. 453554

KANWAL, H. - ASHRAF, M. - HAMEED, M. 2013. Water relations and ionic composition in the seedlings of some newly developed and candidate cultivars of wheat (Triticum aestivum L.) under saline conditions. In Pakistan Journal of Botany, vol. 45, no. 4, pp.1221-1227.

LANDAU, S. - FRIEDMAN, S. - BRENNER, S. - BRUCKENTAL, I. - WEINBERG, Z.G. - ASHBELL, G. - HEN, Y. - DVASH, L. - LESHEM, Y. 2004. The value of safflower (Carthamus tinctorius) hay and silage grown under Mediterranean conditions as forage for dairy cattle. In Livestock Production Science, vol. 88, no. 3, pp. 263-271. DOI: 10.1016/j.livprodsci.2003.11.011

LARAUS, J. 2004. The problems of sustainable water use in the Mediterranean and research requirements for agriculture. In Annals of Applied Biology, vol. 144, no. 3, pp. 259-272. DOI:10.1111/j.1744-7348.2004. tb00342.x

LAWLOR, D.W. - CORNIC, G. 2002. Photosynthetic carbon assimilation and associated metabolism in relation to water deficits in higher plants. In Plant, cell \& environment, vol. 25, no. 2, pp. 275-294. DOI: $10.1046 /$ j.00168025.2001.00814.x

OVERPECK, J.T. - COLE, J.E. 2006. Abrupt change in Earth's climate system. In Annual Review of Environment and Resources, vol. 31, pp. 1-31. DOI: 10.1146/annurev.energy.30.050504.144308 
PEEL, M.C. - FINLAYSON, B.L. - MCMAHON, T.A. 2007 Updated world map of the Köppen-Geiger climate classification. In Hydrology and Earth System Sciences Discussions, vol. 4, no. 2, pp. 439-473. DOI: 10.5194/hess-111633-2007

RAZA, M.A.S. - SHAHID, A.M. - SALEEM, M.F. - KHAN, I.H. - AHMAD, S. - ALI, M. - IQBAL, R. 2017. Effects and management strategies to mitigate drought stress in oilseed rape (Brassica napus L.): a review. In Žemdirbyste (Agriculture), vol. 104, no. 1, pp. 85-94. DOI: 0.13080/za.2017.104.012

RUDOLPHI, S. - BECKER, H.C. - SCHIERHOLT, A. - VON WITZKE-EHBRECHT, S. 2012. Improved estimation of oil, linoleic and oleic acid and seed hull fractions in safflower by NIRS. In Journal of the American Oil Chemists Society, vol. 89, no. 3, pp. 363-369. DOI: 10.1007/s11746011-1920-y

SABAGHNIA, N. - AHADNEZHAD, A. - JANMOHAMMDI, M. 2015. Genetic variation in garden cress (Lepidium sativum L.) germplasm as assessed by some morphological traits. in Genetic Resources and Crop Evolution, vol. 5, no. 62, pp. 733-745. DOI: 10.1007/s10722-014-0192-4
SHAHBAZ, M. - MASOOD, Y. - PERVEEN, S. - ASHRAF, M. 2012. Is foliar-applied glycinebetaine effective in mitigating the adverse effects of drought stress on wheat (Triticum aestivum L.)? In Journal of Applied Botany and Food Quality, vol. 84, no. 2, pp. 192-199. DOI: 10/1094/ CM2003-0804-02-RS

TEJERO, I.G. - ZUAZO, V.H.D. - BOCANEGRA, J.A.J. - FERNÁNDEZ, J.L.M. 2011. Improved water-use efficiency by deficit-irrigation programmes: Implications for saving water in citrus orchards. In Scientia Horticulturae, vol. 128 , no. 3, pp. 274-282. https://doi.org/10.1016/j.scienta.2011.01.035

WANI, A.S. - AHMAD, A. - HAYAT, S. - TAHIR, I. 2016. Is foliar spray of proline sufficient for mitigation of salt stress in Brassica juncea. In Environmental Science and Pollution Research, vol. 23, no. 13, pp. 13413-13423. DOI: 10.1007/ s11356-016-6533-4

Received: August 31, 2017 